Documento de Trabajo 2008-003

"THE "NEW CONSENSUS" AND THE
POST-KEYNESIAN APPROACH TO
THE ANALYSIS OF LIQUIDITY TRAPS"

Alfonso PALACIO-VERA

FACULTAD DE CIENCIAS ECONOMICAS Y EMPRESARIALES UNIVERSIDAD COMPLUTENSE DE MADRID VICEDECANATO

Campus de Somosaguas, 28223 MADRID. ESPAÑA. 
THE "NEW CONSENSUS" AND THE POST-KEYNESIAN APPROACH TO THE ANALYSIS OF LIQUIDITY TRAPS 


\title{
THE “NEW CONSENSUS” AND THE POST-KEYNESIAN APPROACH TO THE ANALYSIS OF LIQUIDITY TRAPS
}

\author{
By \\ Alfonso Palacio-Vera \\ Universidad Complutense de Madrid (Spain)
}

\begin{abstract}
We compare the "New Consensus" (NC) in macroeconomics as expounded in Woodford (2003) and the Post-Keynesian (PK) approach regarding the causes of a "liquidity trap" (LT). We argue that in the $\mathrm{NC}$ a LT is a phenomenon caused by unusually large transitory shocks that depress the "neutral" interest rate temporarily. We show that this is the case because it is assumed that the "neutral" or "natural" interest rate converges in the long run to a gravitation center whose (positive) lower bound is determined by the rate of time preference of the representative household. By contrast, in the PK approach, the economy may also exhibit a "structural" or long-lasting LT even in the absence of large adverse shocks. This may be the case if a combination of high precautionary saving, low investment spending and stringent conditions for access to bank credit stemming from a high degree of uncertainty and liquidity preference makes the sum of the steady-growth "neutral" interest rate and the inflation rate fall short of the term/risk premium on long-term interest rates.
\end{abstract}

JEL Classification: B50, E12, E24, E50

Key words: Neutral interest rate, liquidity trap, New Consensus in macroeconomics, credit rationing and liquidity preference 


\section{THE “NEW CONSENSUS” AND THE POST-KEYNESIAN APPROACH TO THE ANALYSIS OF LIQUIDITY TRAPS}

\section{1.- Introduction}

The most salient feature of the institutional framework that characterizes most, if not all, present-day OECD economies is that the central bank (hereafter $\mathrm{CB}$ ) fine-tunes the economy through conventional monetary policy actions with a view to achieving an inflation target in the medium-term. We define the former as the regular actions that characterize the day-to-day setting of short-term nominal rates by the CB. However, the latter are subject to a zero lower bound (hereafter ZB). This constraint arises because, in a money-using economy, individuals will not be willing to hold any financial asset other than money when the nominal yield of the former is equal or less than zero. Its existence may cause a "liquidity trap" (hereafter LT), i.e., a situation where the $\mathrm{CB}$ is unable to push real interest rates down far enough so as to keep inflation constant in the absence of supply shocks. ${ }^{1}$ The existence of the ZB has been well-known for a long time. Yet, it has only been of recent that mainstream economists have focused their attention on it. Research on the causes and policies to deal with a LT has been led mainly by proponents of the "New Consensus" in macroeconomics (hereafter NC). ${ }^{2}$ Two events explain, according to us, this phenomenon. First, it has become much clearer, especially since the early 1990s, that CBs fine-tune the economy through changes in interest rates rather than through changes in the monetary base. Second, there is the protracted period of sluggish growth and deflation experienced by the Japanese economy since the 1990s and its attribution by some prominent scholars to the occurrence of a LT (Krugman, 1998; Svensson, 2005). 
The main contribution of this study is to identify a number of key differences in the diagnosis of the occurrence of a LT in the NC and the Post-Keynesian (hereafter PK) approach. According to us, the crucial difference is that, in the former, a LT is viewed as a fairly rare and transitory situation which may emerge in the wake of large adverse shocks that depress the "neutral" or "natural" interest rate. By contrast, in the PK approach, an economy may also exhibit a "structural" or long-lasting LT. This will be the case if a perverse combination of high precautionary saving, low investment spending by firms, and stringent bank credit conditions for firms and households alike stemming from a high degree of liquidity preference makes the sum of the steady-growth "neutral" interest rate and the inflation rate fall short of the term premium on long-term interest rates.

The structure of the paper is as follows. Section 2 presents a formal definition of a LT and identifies the factors that may engender it within a general framework. Section 3 reviews briefly the NC approach taking the influential contribution in Woodford (2003) as a benchmark. Section 4 expounds the PK approach to the explanation of the LT vis-àvis the NC approach. Section 5 expounds a simple PK macroeconomic model for a closed economy without a government sector that illustrates the PK position with regard to the occurrence of a "structural" LT. Section 6 summarizes and concludes.

\section{2.- The liquidity trap}

A LT is usually defined as a situation in which the real interest rate (in a closed economy without a government sector) at which saving at the employment rate consistent with constant inflation and investment would be equal is negative (Krugman, 1998, p. 
150). In a LT conventional monetary policy becomes 'impotent because nominal interest rates are at or near zero: injecting monetary base into the economy has no effect, because base and bonds are viewed by the private sector as perfect substitutes' (Krugman, 1998, p. 141). If we denote by $\omega$ the minimum (ex-ante) actual real interest rate that a CB can set and by $r^{n}$ the "neutral" interest rate, we may define a LT as a situation where:

$$
r^{n} \prec \omega
$$

where $r^{n}$ is the long-term real interest rate which is neutral with respect to the inflation rate and tends neither to increase it nor to decrease it in the absence of supply shocks If we think of $r$ as a long-term interest rate, then $\omega$ will be positive because lenders will require a time-varying term premium $\mu \succ 0$ either to grant credit or to purchase longdated securities. ${ }^{3}$ Post-Keynesians insist that the time-varying nature of $\mu$ stems from changes in the degree of "liquidity preference" (hereafter LP) of investors and financial intermediaries respectively (see, for instance, Wells, 1983, p. 533). Next, if we assume, for simplicity, that the expected rate of inflation equals the actual inflation rate we have:

$$
\omega=\mu-\pi^{e}=\mu-\pi
$$

Therefore, we say that an economy is in a LT if:

$$
r^{n}+\pi \prec \mu
$$

Expression (3) tells us that the lower are $r^{n}$ and $\pi$, and the higher is $\mu$ the more likely it is that an economy will exhibit a LT in the wake of either a favorable supply shock or an unfavorable demand shock that pushes $\pi$ and $r^{n}$ down respectively. Finally, if we replace $r^{n}$ in (3) by the steady-growth "neutral" interest rate, then we say that the economy exhibits a "structural" or long-lasting LT. 


\section{3.- The liquidity trap in the "New Consensus" approach}

A large number of mainstream economists have recently evaluated the likelihood of economies exhibiting a LT and the policy options that may remove this constraint. Two recent Symposiums are devoted to this topic; the 2000 Symposium on 'Monetary Policy at the Zero Lower Bound' published in the Journal of Money, Credit, and Banking and the 2004 Symposium on 'Policies to deal with deflation' published in the American Economic Review. A summary of the former is in Blinder (2000) and an evaluation of the different proposals is in Bernanke and Reinhart (2004). An aspect these studies address is the possibility that the economy enters a deflationary spiral once the ZB binds. The general verdict is 'that such episodes are fairly rare, even in a low-inflation environment

- about once every hundred years if the target rate of inflation is around zero, given the sort of shocks that have characterized the U.S. economy over the past thirty years' (Reifschneider and Williams, 2000, p. 962). Hence, the general impression is that a deflationary spiral episode may solely come about in the wake of unusually large shocks. Conversely, there is no consensus as to whether unconventional monetary policy options can sort a LT out should it be necessary. Several policy options to deal with a LT have been proposed but, as argued in Reifschneider and Williams (2000, p. 943), a summary of the debate is that 'the likely effectiveness of such actions is unclear from a theoretical perspective, and they have never been put to a definitive test'.

If the conventional wisdom is that a deflationary episode may solely arise in the wake of unusually large transitory shocks, we may wonder why this is so. A first reason is clearly empirical; there has been only one example of an OECD economy experiencing something like a deflationary episode over the past seventy years, Japan in the 1990s. A 
second reason is related to the mainstream notion of the "natural" interest rate. For the purpose of expounding it, we take the study by Woodford (2003) as the canonical version of the NC approach. Woodford (2003) expounds a fully-fledged model based on explicit optimizing foundations where the deviation of the "natural" interest rate from its steadygrowth value is a stochastic process determined by a range of demand and supply shocks. He defines the "natural" interest rate as "the equilibrium real rate of return in the case of fully flexible prices' (Woodford, 2003, p. 248) and names his approach "neo-wicksellian" because output-gaps and, hence, changes in the inflation rate are explained by deviations of the actual real interest rate from the "natural" interest rate. In the "extended" version of his model demand shocks include fiscal policy, investment and "impatience" shocks. The latter modify the rate of time preference of the representative household. Supply shocks consist of productivity shocks to the production function of the representative firm, shocks to the disutility-of-labor function and changes in the amount of physical capital. He concludes that real 'interest rates must increase in response to temporary increases in government purchases or in the impatience of households to consume and decrease in response to temporary increases in labor productivity or in the willingness of households to supply labor' (Woodford, 2003, p. 250). Importantly, he admits that a range of shocks may render the "natural" interest rate negative, although he implies that this will be a transitory situation:

'The present theory allows for variation over time in the natural rate for a variety of reasons, and there is no reason why it should not sometimes be negative. (The model 
does imply a positive average level of the natural rate, determined by the rate of time preference of the representative household)' (Woodford, 2003, p. 251, emphasis added).

To this date, there is no presentation of the NC model couched in a growth setting so we need to make use of "optimal" growth theory to extrapolate Woodford's results to a growing economy. According to it, the optimality condition for saving yields the following "balanced growth" condition:

$$
r^{*}=\frac{a}{\sigma}+n+\vartheta
$$

where $r^{*}$ denotes the steady-growth "natural" interest rate, $a$ denotes the rate of laboraugmenting technological change, $n$ denotes the rate of population growth, $\sigma$ denotes the inter-temporal elasticity of substitution in consumption, and $\vartheta$ denotes the rate of time preference of the representative household. ${ }^{4}$ Since $a$ and $n$ will be positive in a growing economy, $r^{*}$ is positive and its lower bound is $\vartheta$. Finally, in the stationary state we have that $a=n=0$ and, hence, $r^{*}=\vartheta$.

Woodford's assumption that the average "natural" interest rate is positive implies that the former returns in the long-run to a positive gravitation center provided prices are fully flexible. He does not explain verbally the process whereby the "natural" interest rate converges to its gravitation center. The argument presumably is the following. Let us suppose the "natural" growth rate is zero so that the steady-growth "natural" interest rate initially equals the rate of time preference. If an adverse shock subsequently drives the "natural" interest rate down far enough so as to make the economy exhibit a negative output-gap, inflation will decrease. As long as the inflation rate remains positive or slightly negative, the $\mathrm{CB}$ can lower the nominal interest rate so as to make the actual real 
interest rate fall short of the (average) rate of time preference. Next, the "permanent income hypothesis" (hereafter PIH) embedded in the standard NC model predicts that, for a given permanent income, current consumption will increase relative to consumption in the previous period if the actual real interest rate is lower than the rate of time preference and vice-versa. Meanwhile, households' permanent income will remain constant in spite of reduction in current income since, due to the "perfect foresight" assumption embedded in the standard NC model, it is assumed to depend on future (exogenous) potential output (Clarida et al., 1999, p. 1675). Consequently, as current consumption increases relative to permanent income, the (negative) output-gap will narrow and the "natural" interest rate will increase. This process will continue as long as the actual real interest rate falls short of the rate of time preference. Eventually, the actual and the "natural" interest rate will equal the (average) rate of time preference and the output-gap will be zero. ${ }^{5}$

Several comments are in order. First, the function of the "natural" interest rate in the NC approach is equivalent to the "neutral" interest rate as defined above, namely, the real interest rate compatible with constant inflation in the absence of transitory supply shocks since, as Woodford (2003, p. 248) notes, 'the natural rate of interest is just the real rate of interest required to keep aggregate demand equal at all times to the natural rate of output'. Second, as recognized by proponents of the NC, an economy that exhibits low inflation and a negative output-gap may enter a "deflationary cycle" whereby a decrease in inflation endogenously raises the level of the real rate causing aggregate demand to weaken and push inflation down more, thereby raising the real interest rate even further (Reifschneider and Williams, 2000, p. 942). Thus, if a deflationary spiral is to be avoided, proponents of the NC approach need to assume that the adjustment process described 
above will not be short-circuited by the adverse effect upon aggregate demand of a rising actual real interest rate. ${ }^{6}$ Finally, from the previous discussion we may be tempted to conclude, as Woodford apparently does, that a LT may only occur when the "natural" rate becomes negative. However, as expression (3) above highlights, a LT may also come about when the "neutral" interest rate is positive. This will be the case when, for a given inflation rate, the term premium becomes large enough so as to satisfy (3). In this respect, Cúrdia and Woodford (2008) introduce a number of modifications to the standard NC model to allow for a time-varying spread between rates offered to depositors and paid to borrowers. Notwithstanding the improvement in terms of realism, they fail to recognize that the spread may change endogenously and, crucially, in the opposite direction as the "neutral" interest rate due to changes in the degree of LP.

\section{4.- The Post-Keynesian approach to liquidity traps}

The thrust of our presentation of the PK diagnosis of a LT focuses on the possibility that the steady-growth "neutral" interest rate may become negative and, consequently, the LT may become a "structural" or long-lasting one rather than a "transitory" phenomenon. This, in turn, has deep economic policy implications. In particular, we will argue below that the adjustment of consumption described in the previous section as predicted in the joint rational expectations-PIH (Hall, 1978) may be short-circuited for reasons other than the setting off of a deflationary spiral. The argument is three-fold. First, there is the typical Keynesian assertion about the impact of current disposable income and firms' profits on current consumption and investment spending respectively. This means that adverse demand shocks may elicit "effective demand 
failures" whereby output becomes the adjusting variable. Second, we will show that the maximization of households' lifetime consumption profile subject to a lifetime budget constraint that lies at the heart of the arbitrage process described above may, under uncertainty about future income, lead to an equilibrium where the steady-growth "neutral" interest rate falls short of the rate of time preference of the representative household and may become negative. In particular, we show that, even if there is no credit-rationing, an increase in uncertainty will reduce aggregate demand due to (i) an increase in precautionary saving (ii) and low investment and that this, in turn, may reduce potential output growth. Finally, we show that the presence of financial intermediaries like banks who face illiquidity and default risk will tend to exacerbate the adverse effects on aggregate demand of uncertainty.

\section{1.- Effective demand failures}

To make our point clear we take advantage of Leijonhufvud's well-known theory of "effective demand failures" (Leijonhufvud, 1973). According to it, the central issue in macroeconomic theory is the extent to which the economy may properly be regarded as a self-regulating system in which there is an adequate coordination of desired sales and purchases at the market level in the sense that there are powerful homeostatic mechanisms whereby all market excess demand and supplies are eliminated. $\mathrm{He}$ distinguishes between two types of feedback mechanisms: deviation-counteracting and deviation-amplifying mechanisms. In the former, the larger the displacement from the equilibrium, the stronger will be the homeostatic tendencies working to bring the system back. In the latter, the opposite is the case. 
Primary examples of neoclassical deviation-counteracting feedback mechanisms are the adjustments in the composition of aggregate demand prompted by changes in real interest rates as predicated in neoclassical loanable funds theory or the changes in the level of aggregate spending that result from the operation of the "real balance" effect. Examples of multiplier-repercussions are the effects of changes in current income and capacity utilization on current consumption and investment demand respectively. For our purposes, the presence of deviation-amplifying mechanisms implies that the "neutral" interest rate will exhibit autocorrelation even when (exogenous) shocks do not exhibit it. As a result of it, the "neutral" interest rate will exhibit a higher variance as opposed to a scenario where such mechanisms do not exist. ${ }^{7}$ The variance of the "neutral" interest rate is not a determinant of the steady-growth "neutral" interest rate in the $\mathrm{NC}$ approach owing to the presence of assumptions like (i) the identification of households' permanent income with future (per capita) potential output and (ii) perfect creditworthiness of all borrowers. Contrastingly, in the PK approach, higher output volatility leads to more precautionary saving and credit-rationing, higher term premiums, lower investment and, hence, a lower steady-growth "neutral" interest rate. Indeed, it may be argued that the existence of phenomena like precautionary saving and credit-rationing is inextricably linked to the presence of strong deviation-amplifying mechanisms that may drive current output away from potential output for long periods of time.

\section{2.- Precautionary saving}

Consumption appears to track household current disposable income much more closely than predicted by Friedman's PIH (Friedman, 1957). This is normally attributed 
to (i) households' permanent income being sensitive to changes in current income and (ii) the presence of liquidity constraints. According to the joint rational expectations-PIH (Hall, 1978), the individual's permanent income and, therefore, his consumption plans will be revised period by period as new information about future income becomes available. The magnitude of the revisions in response to the realization of the current innovation in income in a given period will be proportional to the latter. Following this approach, Flavin (1981) specified a structural equation relating the change in current disposable consumption to the contemporaneous revision in permanent income (modeled using the income innovation) and the change in current income. The coefficient of the change in income is thus a measure of the marginal propensity to consume out of current income (MPC) and, therefore, the joint rational expectations-PIH can be tested by testing whether the MPC is significantly different from zero. Her empirical results indicate that the observed sensitivity of current consumption to current disposable income is much greater than is warranted by the $\mathrm{PIH}$, even after controlling for the role of current income in signaling changes in permanent income. Likewise, a number of empirical studies show that some groups of households are subject to liquidity constraints. For example, Jappelli and Pagano (1994) investigate whether cross-country differences in liquidity constraints can explain cross-country differences in the aggregate saving rate and find that the former are important to the latter. The observed excess sensitivity of permanent income to changes in current income and the presence of liquidity constraints represent crucial deviation-amplifying mechanisms that are completely absent from the NC model. As noted above, the former is a direct consequence of the "perfect foresight" assumption whereby revisions in permanent income made in response to changes in potential output. 
This means that, at the aggregate level, there is the equivalent of Say's Law whereby an increase in expected future potential output brings about an equivalent increase in current and future aggregate spending (see Palacio-Vera, 2005). In turn, the absence of liquidity constraints in the $\mathrm{NC}$ model stems from the assumption of (i) perfect financial markets and (ii) the "transversality" condition whereby there is no default risk and all borrowers are deemed creditworthy (Goodhart, 2007).

Next, Friedman (1957) repeatedly acknowledged the importance of precautionary saving motives induced by uncertainty about the future level of labor income. In contrast, the crucial assumption that allowed subsequent mainstream theorists to solve their formal maximizing models was that income uncertainty had no effect on consumption either because uncertainty was assumed not to exist - like in the "perfect foresight" model that characterizes the $\mathrm{NC}$ approach — or because the utility function took a special form that ruled out precautionary motives - like in the "certainty equivalent" model in which, consumers are assumed to have quadratic utility functions. In addition, Friedman (1957) asserted that the "permanent income" that determined current spending was something like a mean of the expected level of income in the very near term and that households adopt a much shorter "horizon" than the remainder of their lifetimes. Finally, Friedman indicated that the reason why distant future labor income had little influence on current consumption was "capital market imperfections", which included both the fact that future labor income was uncertain and the difficulty of borrowing against such income.

According to Carroll (2001, p. 25), the main development in consumption theory in the last two decades is that substantial improvements in computer speed have allowed economists to relax the perfect foresight/certainty equivalence assumption and to analyze 
optimal behavior under realistic assumptions about uncertainty. In particular, if consumers are "impatient", in the sense that if there were no uncertainty or liquidity constraints they would spend more than current disposable income and "prudent" in the sense that they have a precautionary saving motive, then the existence of uncertainty about future income entails that the level of consumption of a representative household will, for every possible level of wealth, fall short of the level of consumption implied by the "perfect foresight" consumption model. Buffer-stock behavior arises because impatience makes consumers want to spend down their assets, while prudence makes them reluctant to draw down assets too far. Precautionary saving is thus defined as the amount by which consumption falls as a consequence of uncertainty. ${ }^{8}$

Another consequence of the existence of uncertainty is that 'as wealth approaches infinity, the proportion of future consumption that will be financed out of uncertain labor income approaches zero, so income uncertainty becomes irrelevant to the consumption decision' (Carroll, 2001, p. 32). This implies, as Keynes (1936) argued long ago, that rich people spend a smaller proportion of their income than poorer people. Technically, this means that the consumption function under uncertainty is strongly concave (Carroll and Kimball, 1996). The concavity property thus implies that consumers engage in "bufferstock" saving behavior whereby wealth becomes a "reserve" against uncertainty. As shown in Carroll (1992), there will be some target level of wealth such that, if actual wealth is greater than the target, impatience will outweigh prudence, precautionary saving will decrease and wealth will consequently fall, whereas if wealth is below the target, precautionary saving and wealth will increase. In other words, the concavity 
property implies that precautionary saving increases the marginal propensity to consume out of transitory income shocks since the former relaxes as wealth rises.

The strongest claims on behalf of the precautionary motive come from the work of Carroll (1992). According to him, unemployment expectations are important determinants of consumption because 'when consumers become more pessimistic about unemployment, their uncertainty about future income increases, so their target bufferstock increases, and they increase their saving to build up wealth toward the new target' (Carroll, 1992, p. 62). His simulations show that, contrary to standard life-cycle and permanent income models: (i) even with unchanging expectations about the average future level of labor income, increases in the expected probability of unemployment or a tightening in the borrowing constraints facing households will make them increase their target wealth and saving rate; (ii) the elasticity of the saving rate with respect to the growth rate of personal labor income is positive; (iii) the interest elasticity of saving is approximately zero.

The precautionary demand for saving can thus be described as the extra saving caused by future income being random rather than determinate. Under certainty we have the well-known result in consumption theory that consumption will be growing when the real interest rate is greater than the rate of time preference, and declining when the real interest rate is less than the rate of time preference. However, as noted in Deaton (1992, p. 29), 'if the marginal utility of consumption function is convex, a mean-preserving increase in risk will increase the marginal utility of future consumption, so that current consumption will have to decrease in order to bring the current marginal utility back into equality'. Hence, convexity of the marginal utility function provides a rationale for the 
precautionary demand for saving. ${ }^{9}$ In a seminal paper, Leland (1968) considers a two period model of consumption in which income in the first period and a subjective probability distribution for income in the second period are known. The consumer must determine his consumption for the first period before he knows the actual value of his second period income. He is interested in the level of saving as future income becomes more uncertain about a given expected (mean) value and finds that, under reasonable assumptions, the optimal saving rate of households under uncertainty is higher than under certainty and the higher the degree of uncertainty, the greater will be the optimal saving rate (see also Sandmo, 1970, p. 356). In particular, he shows that, under uncertainty, the Euler equation becomes:

$$
E_{t}\left[u^{\prime}\left(c_{t+1}\right)\right] \succ\left[\frac{1+\vartheta}{1+r_{0}^{*}}\right] u^{\prime}\left(c_{t}\right) \quad \text { if } r_{0}^{*}=\vartheta
$$

where $u^{\prime}\left(c_{t}\right)$ is the marginal utility of consumption $c$ in period $t, \vartheta$ is the discount factor, and $E$ is the expectations operator. The existence of an inequality in the Euler equation (5) stems from the fact that, as uncertainty increases, households' expected marginal utility of future consumption increases relative to the marginal utility of current consumption. Hence, optimizing households will want to reduce current consumption. Nevertheless, an alternative adjustment in the previous Euler equation is that there exists a real interest rate $r_{1}^{*} \prec r_{0}^{*}=\vartheta$ such that, in equilibrium:

$$
E_{t}\left[u^{\prime}\left(c_{t+1}\right)\right]=\left[\frac{1+\vartheta}{1+r_{1}^{*}}\right] u^{\prime}\left(c_{t}\right)
$$

and the greater the degree of uncertainty about future income the larger the gap between $\vartheta$ and $r^{*}$ that will be necessary to reach equilibrium. Thus, if $r=r_{1}^{*} \prec \vartheta$ households will 
not have any incentive to reduce saving further even though the actual real interest rate falls short of the rate of time preference. The theory of precautionary saving also provides a rationale for the Keynesian claim that, even if expected future income remains constant, an increase in uncertainty may elicit an increase in households' saving despite the actual real interest rate being negative.

One might object that a similar result could be obtained if, instead of an increase in uncertainty, there is a decrease in permanent income. Certainly, a decrease in expected future income relative to current income will increase the expected marginal utility of future income thereby creating a wedge between $\vartheta$ and $r^{n}$ in the absence of adjustments in current consumption. However, the downward revision of permanent income cannot last indefinitely. Eventually, households will stop revising it. When this occurs, they will increase current consumption (relative to consumption in the previous period) as long as the actual real interest rate falls short of their rate of time preference and this, in turn, will tend to close the gap between $\vartheta$ and $r^{n}$. Hence, this story can solely account for the emergence of a temporary gap between $\vartheta$ and $r^{n} \cdot{ }^{10}$ By contrast, when a gap between $\vartheta$ and $r^{*}$ emerges in the aftermath of an increase in uncertainty, the former will stay put as long as the latter remains high.

Lastly, we have assumed so far that the rate of time preference of all households is positive. Nevertheless, as Irving Fisher (1930) noted long time ago, there may be some occasions when this does not hold:

'The man's income situation is such that he might even be willing to lend for nothing, or even less than nothing, simply because he would, in such a case, be so 
surfeited with this year's income and so short, prospectively, of next year's income that he would be thankful to get rid of some of this year's superfluity, for the sake of adding even a trifle to next year's meager real income... In such situations a man would be willing to save for the future without any incentive in the form of interest' (Fisher, 1930, p. 248).

It is straightforward to associate the case mentioned in Fisher's quote above with increases in uncertainty about future income, that is, there may be households whose future income becomes so uncertain that, for all purposes, it is "as if" their rate of time preference were negative. Crucially, if the rate of time preference of some households becomes negative in some circumstances, it is no longer the case that the average rate of time preference in the economy will always be positive.

\section{3.- Investment}

Post Keynesians insist that firms' investment is mainly a function of current and expected profitability. The impact of expected future profits in investment spending recognizes the possibility, as Keynes (1936) does, that long-period profit expectations may shift independently of strictly economic results like current gross profits. ${ }^{11}$ The impact of current profits in firms' investment spending stems from the fact that: (i) as proposed in the Kaleckian tradition changes in current profits affect expected profitability and the cost of external finance (Fazzari and Mott, 1986-87) and, (ii) there is an extensive literature that claims that firms' investment expenditure is significantly affected by changes in firms' cash flows (Fazzari et al., 1988; Fazzari and Petersen, 1993). This 
literature is generally based on the premise that capital markets are imperfect in the sense that internal and external capital are not perfect substitutes so that investment may depend on financial factors such as the availability of internal finance, access to new debt or equity finance, or the functioning of particular credit markets. In turn, the main source of imperfections is the presence of asymmetric information that makes it very costly, or even impossible, for providers of external finance to evaluate investment opportunities. As a result of it, the cost of new debt and equity may be substantially higher than the opportunity cost of internal finance generated through cash flow and retained earnings. The impact of cash flows on investment thus constitutes an important deviationamplifying mechanism that reinforces the mechanism that operates through consumption.

\section{4.- Credit-rationing}

In the real world many economic agents are liquidity-constrained in the sense that they do not have sufficient assets to sell or the ability to borrow. Samwick (1995) shows that unconstrained consumers who exhibit a precautionary saving motive behave in ways qualitatively and quantitatively similar to the behavior of liquidity-constrained consumers facing no uncertainty. To be sure, liquidity-constrained households exhibit less flexibility in responding to shocks since the effects of the shocks cannot be spread out over time. In addition, precautionary motives and liquidity constraints interact because the inability to borrow when times are bad provides an additional motive for accumulating assets when times are good, even for impatient consumers (Deaton, 1991). This means that uncertainty will have a bigger effect on expected utility for liquidity-constrained agents than for unconstrained ones. The precautionary saving motive is thus heightened by the 
desire (in the face of uncertainty) to make such constraints less likely to bind (Carroll and Kimball, 2001). In short, in the "buffer-stock" saving model, a tightening in borrowing constraints brings about an increase in precautionary saving or, alternatively, it widens the wedge between $r^{*}$ and $\vartheta$.

Next, the usual PK assumption regarding expectations formation is that borrowers and lenders are subject to "fundamental" uncertainty about the future (Keynes, 1937, p. 113). By such, is meant the idea that the future cannot be reduced to an actuarial calculation of probabilities, whether objective or subjective. In this setting, the analysis of past data or current market signals does not provide reliable information regarding future prospects and therefore, the future is simply not calculable (Davidson, 1991). They also argue that, in many choice situations more can be learned about the factors governing eventual outcomes after decisions have been made. This presents no problem where choices can be completely and costlessly reversed. But things are very different where they cannot. Such irreversibility entails that it may sometimes be rational to suspend judgement and delay commitment until more information has been acquired. In this context, the function of liquidity is that of "giving us time to think" (Hicks, 1974, p. 57). In general, however, decisions cannot be postponed until all the evidence is available and, in such cases the readiness and terms at which commitments to previous choices may be dissolved assumes importance (Runde, 1994, p. 136). Thus, in situations of uncertainty liquid assets carry a premium over illiquid ones. In short, Post Keynesians identify the notion of LP with an environment of "fundamental" uncertainty where the degree of LP is inversely related to the degree of confidence and the reliability of beliefs. In turn, this implies that reduced LP typically accompanies conditions which are conducive to 
increases in the level of economic activity and vice-versa. As discussed above, precautionary saving and expected profitability are two channels through which higher LP may reduce aggregate demand. In addition, Post Keynesians insist that decisions by banks as to whether or not to grant credit play a major role in the expansion of the economy, in the sense that a failure of banks to supply credit will imply that the expansion of expenditure cannot occur: ${ }^{12}$

'A world of ultimate liquidity preference is a world where firms would refuse to produce for fear of indebtedness, where banks would refuse to lend for fear of loan defaults, and where consumers would refuse to spend for fear of unemployment' (Lavoie, 1996, p. 292).

The usual PK argument is that banks accommodate all creditworthy demands for credit, and ration all those demands not deemed creditworthy. In addition, it is postulated that there is always some credit-rationing and that the former increases in recessions due (mainly) to increases in the degree of LP of banks which, in turn, exacerbates output contractions. The earliest reference to credit-rationing in the PK literature is Keynes' comments in the Treatise (Keynes, 1930, p. 212) about the "fringe of unsatisfied borrowers", the size of which can be expanded or contracted so that banks can influence the volume of aggregate spending over the business cycle. The upshot is that the "fringe" represents a permanent situation in the sense that there is always a group of borrowers who are refused credit. ${ }^{13}$ 
For the purposes of this study, two questions naturally arise. First, does creditrationing actually increase in recessions and, if so, why?. Second, does the occurrence of cyclical changes in credit rationing makes it more likely that a "structural" LT comes about?. According to Wolfson (1996, p. 451), 'all that is necessary for a theory of credit rationing based on Keynesian uncertainty is that borrower and lender evaluate the future differently — that is, they have asymmetric expectations' about the riskiness of particular projects whose outcome depends on the future. In particular, for those projects deemed safe by the borrower but deemed too risky by the lender, the borrower will be rationed. In turn, this means that the impact of credit rationing at any point in time can be ascertained by computing the number of projects deemed safe by the borrower relative to the number of projects deemed too risky by the lender. It is not controversial to say that banks tend to increase both price and non-price terms in response to perceptions of higher risk and that perceived risk increases in recessions. However, it will also be the case that the demand for bank credit decreases in recessions. Be that as it may, Wolfson (1996, pp. 459-61) shows empirical evidence that suggests that interest rate spreads, non-price standards and credit rationing increase altogether near business-cycle peaks and decrease near troughs. Why is this so?

Banking firms need to reach a compromise between profit maximization on one hand and illiquidity and default risk on the other hand. An increase in lending by an individual bank (to creditworthy borrowers) relative to lending by the rest of the banks leads, in normal circumstances, to higher expected future profits for that bank but also brings about a decrease in its reserves to capital ratio and its reserves to deposits ratio. The specific balance an individual bank reaches will depend on its degree of LP which, in 
turn, will depend on its state of confidence. By this, we mean 'how highly we rate the likelihood of our best forecast turning quite wrong' (Keynes, 1936, p. 148). According to Keynes (1936, p. 152), even though we know we do not know the future, we tend to act as if we do by relying on conventions. The former represent the non-technical vision of economic agents. As uncertainty increases, agents will 'place less trust in the past as a guide to the future and become more wary of irreversible commitments that increase the threat of illiquidity' (Dymski, 1992, p. 317). In general, the weaker the state of confidence is, the more likely it is that opinion will change. In turbulent times like recessions conventions break down and change. In turn, a turbulent time comes about when there is a significant amount of dissonance between agents' anticipations about cash flows and ex post realizations (Minsky, 1975).${ }^{14}$ As for banks, an increase in "turbulence" will bring about a perceived change in borrowers' creditworthiness that will change their conventional valuation of the risk of lending and, hence, the size of interest rates spreads and the extent of credit rationing.

The last question we address is whether the existence of credit-rationing and "fundamental" uncertainty renders the occurrence of a "structural" LT more likely. As noted above, banks tighten credit standards and set higher interest rate spreads before business cycle peaks. This will tend to reinforce the deviation-amplifying mechanisms alluded to above by exacerbating the response of current consumption and investment to decreases in current disposable income and profits respectively. First, households who are not subject to binding liquidity constraints will increase precautionary saving. Second, households or firms who are subject to binding liquidity constraints will not be able to maintain, let alone increase, current spending even if the actual real interest rate 
falls short of the rate of time preference or the expected profit rate respectively. The convergence of the "neutral" interest rate to the (average) rate of time preference will thus be short-circuited so the former will settle at a level that is inversely related to the degree of uncertainty and credit-rationing.

To finish off this section, we should like to note that the PK approach stands in marked contrast to the standard NC approach where the assumptions of "perfect" capital markets and creditworthiness of all borrowers imply the absence of credit-rationing:

'Amongst the several problems/disadvantages of this current consensus is that, in order to make a rational expectations micro-founded model mathematically and analytically tractable it has been necessary in general to impose some (absurdly) simplifying assumptions, notably the existence of representative agents, who never default. This latter (nonsensical) assumption goes under the jargon term as the transversality condition' (Goodhart, 2008, p. 13).

Admittedly, there are attempts to render the standard NC model more realistic by introducing household heterogeneity and interest rate spreads (Cúrdia and Woodford, 2008; Canzoneri et al., 2008). ${ }^{15}$ However, as Goodhart (2007) notes, some fundamental problems like the absence of default risk and credit-rationing remain to be addressed.

\section{5.- A simple Post-Keynesian model}

We now expound a simple PK model for a closed economy without a government sector. We intend to utilize it as a benchmark to be contrasted to the $\mathrm{NC}$ model. We 
display the model in the first two subsections and present the analysis of its steady growth properties and short-run behavior in subsequent subsections.

\section{1.- The supply side}

Let us consider a one-sector economy with two inputs, labor and capital, and assume that (i) there is a large number of identical firms and (ii) they all utilize the same technology. If we aggregate across all firms, we may define potential output $\bar{Y}$ as:

$$
\bar{Y}=\lambda \cdot \bar{N} \leq v \cdot K
$$

where $\bar{N}$ denotes the level of employment that keeps inflation constant in the absence of transitory supply shocks, $K$ denotes the aggregate capital stock, and $\lambda$ and $v$ denote respectively the productivity of labor and capital when the factors are fully utilized. The current rate of capacity utilization is:

$$
u=\frac{Y}{v \cdot K} \leq 1
$$

where $Y$ denotes aggregate output. We assume there is an "employment rate compatible with constant inflation" (hereafter CIER) which results from the conflicting income claims of workers and firms so that inflation will increase if the actual employment rate is higher than the CIER and vice-versa. Thus, the CIER represents a short-run "inflation barrier" albeit one which may be affected by the level and time path of aggregate demand

if it exhibits hysteresis effects. We define the rate of capacity utilization when $Y=\bar{Y}$ as the "constant inflation capacity utilization" or CICU which we denote by $\bar{u}$ or:

$$
\bar{u}=\frac{\bar{Y}}{v K}=\frac{\lambda}{v} \cdot \frac{\bar{N}}{K}=\left(\frac{\lambda}{v}\right) \cdot\left(\frac{\bar{e} \cdot L}{K}\right) \leq 1
$$


where we denote the by $\bar{e}$ the CIER, by $L$ the labor force and $\bar{N}=\bar{e} \cdot L$. For simplicity, we assume there is no overhead labor and firms are fully integrated, producing all the materials required for their final output so that prime costs are made up only of labor costs. We also assume that firms set a constant mark up over prime costs. Finally, the "natural" rate of growth is:

$$
g_{n}=n+a
$$

where $a$ is the growth rate of labor productivity $\lambda$.

\section{2.- The demand side}

The equilibrium condition in the goods market for a closed economy without a government sector when current output is equal to potential output is:

$$
s\left(r^{n}, z\right) \cdot \bar{Y}=I
$$

where $s$ is the saving rate, $I$ is (gross) investment, and $z$ is a vector of variables to be filled below. $r^{n}$ is the "neutral" interest rate which we define here as the real interest rate that makes planned saving at potential output equal to planned gross investment. It is better thought of as a long-term rate. If we divide (11) through by $K$ and denote the rate of capital accumulation by $g$ and the rate of depreciation of physical capital by $\psi$ we get:

$$
s \cdot v \cdot \bar{u}=g+\psi
$$

We now turn our attention to functions $s$ and $g$. We assume that the saving rate $s$ is a function of the rate of inflation $\pi$, the rate of growth of output $\hat{y}$, the real interest rate $r$ and a measure of shocks $\varepsilon_{s}$ that includes changes in the degree of LP or:

$$
s=s\left(\pi, \hat{y}, r, \varepsilon_{s}\right)
$$


where $s_{\hat{y}} \succ 0, s_{\pi} \prec 0, s_{r} \succ 0, \varepsilon_{s}$ is a stochastic variable and the subscripts in function $s$ denote partial derivatives. As noted above, a positive sign of $s_{\hat{y}}$ is an implication of the "buffer-stock" theory of saving. ${ }^{16}$ However, it is here justified by Marglin's (1984) "disequilibrium hypothesis" according to which household saving relative to disposable income increases when income rises faster than households can adapt their spending habits whereas the opposite occurs when income falls faster than households can rein in their spending. We also noted above that the "buffer-stock" theory of saving predicts a negligible elasticity of saving with respect to the interest rate. By contrast, the positive sign of $s_{r}$ is here attributed to the presence of distribution effects rather than to the optimizing behavior of households. If we assume that the average propensity to consume of net debtors is higher than that of net creditors, then a rise in the real interest rate will redistribute income away from net debtors and towards net creditors thereby raising the aggregate saving rate. ${ }^{17}$ The sign of $s_{\pi}$ is attributed to the presence of consumption delay effects and inside-debt effects that depress private spending when inflation decreases and vice-versa. ${ }^{18}$

Next, let us assume that firms have a desired rate of capacity utilization $u^{*} \prec 1$ so they expand productive capacity when $u \succ u^{*}$ and stop expanding it when $u \prec u^{*}{ }^{19} \mathrm{~A}$ theoretical justification for this assumption is that firms prefer to keep some capacity idle in order to be able to respond rapidly to unanticipated favorable demand shocks and deter the entry of rivals into the industry (Spence, 1977). This can be conveniently captured by defining the rate of accumulation, $g$ as:

$$
g=v \cdot u \cdot f\left(u-u^{*}, \varepsilon_{g}\right)
$$


where $f_{u} \succ 0$ is inversely proportional to the size of the construction and capital goods delivery lags, $f(0)=\bar{f} \succ 0, E\left(\varepsilon_{g}\right)=0$ and $\varepsilon_{g}$ represents shocks affecting $\bar{f}$. Parameter $\bar{f}$ captures firms' expected future demand growth and, hence, expected profitability. In turn, we assume that the investment function $f$ adopts a linear form or: ${ }^{20}$

$$
f\left(u-u^{*}, \varepsilon_{g}\right)=\bar{f}+f_{u} \cdot\left(u-u^{*}\right)
$$

Inserting (14) into (12) we obtain the equilibrium condition in the goods market when $Y=\bar{Y}$ or:

$$
s\left(\pi, \hat{y}, r^{n}, \varepsilon_{s}\right)=f\left(\bar{u}-u^{*}, \varepsilon_{g}\right)+\frac{\psi}{v \bar{u}}
$$

Next, we assume that the saving function $s$ adopts a linear form or:

$$
s=\bar{s}+s_{\hat{y}} \cdot \hat{y}+s_{\pi} \cdot \pi+s_{r} \cdot r
$$

where $\bar{s}$ is a shift term determined by households' preferences, institutional factors, and the degree of LP. If we insert (15) and (17) into (16) and re-arrange, we obtain the (shortrun) rate of growth of output:

$$
\hat{y}=\frac{\bar{f}-\bar{s}+f_{u} \cdot\left(u-u^{*}\right)-s_{\pi} \cdot \pi-s_{r} \cdot r}{s_{\hat{y}}}+\frac{\psi}{s_{\hat{y}} \cdot v \cdot u}
$$

Finally, $r^{n}$ is the real interest rate that yields $u=\bar{u}$ in the short run. A solution for $r^{n}$ can be obtained by setting $u=\bar{u}$ in (18) and rearranging: ${ }^{21}$

$$
r^{n}=\frac{\bar{f}-\bar{s}+f_{u} \cdot\left(\bar{u}-u^{*}\right)+\frac{\psi}{v \cdot \bar{u}}-s_{\hat{y}} \cdot \hat{y}-s_{\pi} \cdot \pi}{s_{r}}
$$

Therefore, an increase in the degree of uncertainty will tend to raise $\bar{s}$ and lower $\bar{f}$ thereby pushing $r^{n}$ downward and vice-versa. ${ }^{22}$ 


\section{3.- Steady-growth analysis}

Steady-growth equilibrium corresponds to a period of sufficient length to enable all variables in the economy to settle at constant rates in the absence of new disturbances. If we denote by $\pi^{*}$ the inflation target of the CB we have that, in a hypothetical steady growth scenario, $\hat{y}=g_{n}, u=\bar{u}=u^{*}, \pi=\pi^{*}$ and $\varepsilon_{s}=\varepsilon_{g}=\varepsilon_{\pi}=0$ so that the two following conditions must be satisfied:

and

$$
v \cdot u^{*} \cdot \bar{f}=g_{n}=\hat{y}
$$

Equation (20) tells us that, in steady-growth, the rate of accumulation must equal the "natural" growth rate. Equation (21) is the counterpart to equation (12) for the steady growth case. In order to get an explicit solution for the steady-growth "neutral" interest rate $r^{*}$ we insert (17) into (21) and re-arrange:

$$
r^{*}=\left[\frac{g_{n}+\psi}{v \cdot u^{*}}-\bar{s}-s_{\pi} \pi^{*}-s_{\hat{y}} g_{n}\right] \frac{1}{s_{r}}
$$

Thus, $r$ is a function of the "natural" rate of growth, the target inflation rate, the depreciation rate and the saving rate. It can be interpreted as the real interest rate where 'all markets are in equilibrium and there is therefore no pressure for any resources to be

redistributed or growth rates for any variables to change' (Archibald and Hunter, 2001, p. 20). It follows that:

$$
\frac{\partial r^{*}}{\partial \bar{s}}=\frac{-1}{s_{r}} \prec 0
$$

so that, for instance, an increase in precautionary saving pushes $r^{*}$ down and vice-versa. Likewise, a decrease in the "natural" growth rate will push $r^{*}$ downward: 


$$
\frac{\partial r^{*}}{\partial g_{n}}=\left(\frac{1}{v \cdot u^{*}}-s_{\hat{y}}\right) \cdot \frac{1}{s_{r}} \succ 0
$$

Therefore, unlike in the NC approach, $r^{*}$ may become negative if $g_{n}$ is very low and $\bar{s}$ is relatively large. In this respect, it has been argued that the main cause of the recent Japanese stagnation is its relatively high saving rate and its low "natural" rate of growth (see, for instance, Krugman, 1998, pp. 173-4 and Nakatani and Skott, 2007). ${ }^{23}$ Finally, Post Keynesians insist that the "natural" growth rate is a positive function of the growth of aggregate demand. ${ }^{24}$ This means that, if sustained for a sufficiently long period of time, a low investment rate may push the "natural" growth rate down and, through this channel, it may reduce $r^{*}$.

\section{6.- Summary and conclusion}

The purpose of this study was to identify the distinguishing features of a PostKeynesian (PK) approach vis-à-vis the New Consensus (NC) in macroeconomics with respect to the explanation of the occurrence of a "liquidity trap" (LT). We characterized the NC approach by Woodford's (2003) influential study which predicts that a LT is likely to be a transitory phenomenon that may solely occur as the result of relatively large shocks that (temporarily) depress the "natural" interest rate. We showed that this is an implication of the neoclassical premise that there is a positive gravitation center towards which the "natural" interest rate converges in the long run. However, we argued that such convergence is based on unrealistic assumptions about economic agents' behavior and the institutional framework in which they make decisions like the assumptions of perfect foresight, perfect capital markets and absence of credit-rationing. By contrast, we showed 
that, in the PK approach, all agents face the risk of default and make decisions under conditions of "fundamental" uncertainty about the future. As such, we showed that the main implication of the PK model vis-à-vis the $\mathrm{NC}$ model is that economies may exhibit "structural" or long-lasting liquidity traps. This will be the case, for instance, if a perverse combination of high household saving, low investment and stringent conditions for access to credit stemming from a high degree of liquidity preference makes the sum of the steady-growth "neutral" interest rate and the inflation rate fall short of the term premium on long-term interest rates. Finally, the main policy implication stemming from the PK vis-à-vis the NC model is that, even if a deflationary spiral does not set off, the economy may remain stuck in a LT for long periods of time unless forceful expansionary policy measures are duly implemented.

\section{References}

Arestis, P. \& Sawyer, M.C. 2008. A critical reconsideration of the foundations of monetary policy in the new consensus macroeconomic framework, Cambridge Journal of Economics, 32(5), pp. 761-779.

Archibald, J. \& Hunter, L. 2001. What is the Neutral Real Interest Rate, and How Can We Use It?, Reserve Bank of New Zealand Bulletin, 64(3), pp. 15-28.

Bernanke, B.S. \& Reinhart, V.R. 2004. Conducting Monetary Policy at Very Low Shortterm Interest Rates, American Economic Review, Papers and Proceedings, 94(2), May, pp. 85-90.

Blinder, A.S. 2000. Monetary Policy at the Zero Lower Bound: Balancing the Risks, Journal of Money, Credit and Banking, 32(4), November, pp. 1093-1099.

Carroll, C.D. 1992. The Buffer-Stock Theory of Saving: Some Macroeconomic Evidence, Brookings Papers on Economic Activity, 2, pp. 61-156. 
Carroll, C.D. 2001. A Theory of the Consumption Function, With and Without Liquidity Constraints, Journal of Economic Perspectives, 15(3), pp. 23-45.

Carroll, C.D. \& Kimball, M.S. 1996. On the Concavity of the Consumption Function, Econometrica, 64(4), pp. 981-992.

Carroll, C.D. \& Kimball, M.S. 2001. Liquidity Constraints and Precautionary Saving, NBER Working Paper, no. 8496.

Carroll, C.D. \& Samwick, A.A. 1998. How Important is Precautionary Saving?, Review of Economics and Statistics, 80(3), pp. 410-19.

Canzoneri, M. B., Cumby, R. Diba, B. \& López-Salido, J.D. 2008. Monetary Aggregates and Liquidity in a Neo-Wicksellian Framework, CEPR, WP-6813, May.

Clarida, R., Galí, J. \& Gertler, M. 1999. The Science of Monetary Policy: A New Keynesian Perspective, Journal of Economic Literature, 37, December, pp. 1661-707.

Corrado, C. \& Mattey, J. 1997. Capacity Utilization, Journal of Economic Perspectives, 11(1), pp. 151-67.

Cúrdia, V. \& Woodford, M. 2008. Credit Frictions and Optimal Monetary Policy, October, mimeo.

Davidson, P. 1991. Is Probability Theory Relevant for Uncertainty?. A Post Keynesian Perspective, Journal of Economic Perspectives, 5(1), pp. 129-43.

Deaton, A. 1991. Saving and Liquidity Constraints, Econometrica, 59(5), pp. 1221-48.

Deaton, A. 1992. Understanding Consumption, Oxford: Oxford University Press.

Dymski, G. A. 1992. A "new view" of the role of banking firms in Keynesian monetary theory, Journal of Post Keynesian Economics, 14(3), pp. 311-320. 
Fazzari, S. \& Mott, T. L. 1986-87. The investment theories of Kalecki and Keynes: an empirical study of firm data, 1970-1982, Journal of Post Keynesian Economics, 9(2), pp. 171-87.

Fazzari, S. M., Hubbard, R. G., Petersen, B. C., Blinder, A. S. \& Poterba, J. M. 1988. Financing constraints and corporate investment, Brookings Papers on Economic Activity, 1, pp. 141-206.

Fazzari, S. \& Petersen, B.C. 1993. Working Capital and Fixed Investment: New Evidence on Financing Constraints, Rand Journal of Economics, 24(3), pp. 328-342.

Ferderer, J. P. 1993. Does uncertainty affect investment spending?, Journal of post Keynesian Economics, 16(1), pp. 19-35.

Fisher, I. 1930. The Theory of Interest, New York: Augustus M. Kelley.

Flavin, M.A. 1981. The Adjustment of Consumption to Changing Expectations about Future Income, Journal of Political Economy, 89(5), pp. 974-1009.

Friedman, M.A. 1957. A Theory of the consumption Function, Princeton: Princeton University Press.

Garner, A. 1994. Capacity Utilization and U.S. Inflation, Federal Reserve Bank of Kansas City, Fourth Quarter, pp. 5-21.

Goodhart, C.A.E. 2007. Whatever Became of the Monetary Aggregates?, National Institute Economic Review, April, issue 200, pp. 56-61.

Goodhart, C.A.E. 2008. The Continuing Muddles of Monetary Theory: A Steadfast Refusal to Face Facts, paper presented in the Conference "Macroeconomic Policies on Shaky Foundations - Whither Mainstream Economics?", $1^{\text {st }}$ November, Berlin.

Guttentag, J. \& Herring, R. 1984. Credit Rationing and Financial Disorder, Journal of Finance, 39(5), pp. 1359-82.

Hall, R.E. 1978. Stochastic Implications of the Life Cycle-Permanent Income Hypothesis: Theory and Evidence, Journal of Political Economy, 86(6), pp. 971-87. 
Hicks, J. 1974. The Crisis in Keynesian Economics, Oxford: Basil Blackwell.

Jappelli, T. \& Pagano, M. 1994. Saving, Growth, and Liquidity Constraints, Quarterly Journal of Economics, 109, February, pp. 83-109.

Keynes, J. M. 1930. A Treatise on Money, 2 vols., London: Macmillan.

Keynes, J. M. 1936. The General Theory of Employment, Interest and Money, Cambridge, Macmillan.

Keynes, J. M. 1937. The General Theory of Employment, Quarterly Journal of Economics, 51(2), pp. 209-23.

Kregel, J. 2004. Krugman on the Liquidity Trap: Why Inflation Will not Bring Recovery in Japan, in R. Arena and N. Salvadori (eds.) Money, Credit and the Role of the State: Essays in Honour of Augusto Graziani, pp. 225-38, Aldershot (UK): Ashgate.

Krugman, P. 1998. It's Baaack: Japan's Slump and the Return of the Liquidity Trap, Brookings Papers on Economic Activity, 2, pp. 137-205.

Lavoie, M. 1996. Horizontalism, Structuralism, Liquidity Preference and the Principle of Increasing Risk, Scottish Journal of Political Economy, 43(3), August, pp. 275-300.

Leijonhufvud, A. 1973. Effective Demand Failures, Swedish Journal of Economics, 75(1) pp. 27-48.

Leland, H. E. 1968. Saving and Uncertainty: The Precautionary Demand for Saving, Quarterly journal of Economics, 82(3), pp. 465-73.

León-Ledesma, M.A. \& Thirlwall, A.P. 2002. The endogeneity of the natural rate of growth, Cambridge Journal of Economics, 26, July, pp. 441-59.

Marglin, S.A. 1984. Growth, Distribution and Prices, Cambridge (MA): Harvard University Press. 
Meyer, L.H. 2001. Does Money Matter?, Federal Reserve Bank of St. Louis Review, September/October, pp. 1-15.

Minsky, H.P. 1975. John Maynard Keynes, New York: Columbia University Press.

Modigliani, F. \& Cao, L. 2004. The Chinese Saving Puzzle and the Life-Cycle Hypothesis, Journal of Economic Literature, 42(1), pp. 145-170.

Nakatani, T. \& Skott, P. 2007. Japanese growth and stagnation: a Keynesian perspective, Structural Change and Economic Dynamics, 18(3), pp. 306-332.

Neal, P. 1996. Keynesian uncertainty in credit markets, Journal of Post Keynesian Economics, 18(3), pp. 397-418.

Palacio-Vera, A. 2005. The 'modern' view of macroeconomics: some critical reflections, Cambridge Journal of Economics, 29(4), pp. 747-67.

Palley, T.I. 2008. Keynesian models of deflation and depression revisited, Journal of Economic Behavior and Organization, 68(1), pp. 167-77.

Reifschneider, D. \& Williams, J. C. 2000. Three Lessons for Monetary Policy in a LowInflation Era, Journal of Money, Credit and Banking, 32(4), November, pp. 936-966.

Romer, D. 1996. Advanced Macroeconomics, New York: McGraw-Hill.

Runde, J. 1994. Keynesian uncertainty and liquidity preference, Cambridge Journal of Economics, 18(2), pp. 129-44.

Sandmo, A. 1970. The Effect of Uncertainty on Saving Decisions, Review of Economic Studies, 37(3), pp. 353-60.

Samwick, A.A. 1995. The Limited Off-set Between Pension Wealth and the Other Private Wealth: Implications of Buffer-Stock Saving, Manuscript, Department of Economics, Dartmouth College. 
Spence, A.M. 1977. Entry, Capacity, Investment and Oligopolistic Pricing, Bell Journal of Economics, 8(2), pp. 534-44.

Stiglitz, J. E. 1988. Money, Credit, and Business Fluctuations, Economic Record, 64, December, pp. 307-22.

Stiglitz, J. E. \& Weiss, A. 1981. Credit Rationing in Markets with Imperfect Information, American Economic Review, 71(3), pp. 393-410.

Summers, L. H. 1981. Capital Taxation and Accumulation in a Life Cycle Growth Model, American Economic Review, 71(4), pp. 533-44.

Svensson, L.E.O. 2005. Monetary Policy and Japan's Liquidity Trap, paper presented at the ESRI International Conference on Policy Options for Sustainable Economic Growth in Japan, Tokyo, September 14, 2005.

Weber, A.A., Lemke, W. and Worms, A. 2008. How useful is the concept of the natural real rate of interest for monetary policy?, Cambridge Journal of Economics, 32(1), pp. 49-63.

Wells, P. 1983. A post Keynesian view of liquidity preference and the demand for money, Journal of Post Keynesian Economics, 5(4), pp. 523-536.

Wicksell, K. 1911. Böhm-Bawerk's Theory of Capital, in: Erik Lindahl (Ed.) Knut Wicksell-Selected Papers on Economic Theory (London: Allen \& Unwin) 1958, pp. 17685.

Wolfson, M. H. 1996. A Post Keynesian theory of credit rationing, Journal of Post Keynesian Economics, 18(6), pp. 443-70.

Woodford, M. 2003. Interest and Prices: Foundations of a Theory of Monetary Policy, Princeton, NJ, Princeton University Press.

Wray, L.R. 1992. Commercial banks, the central bank, and endogenous money, Journal of Post Keynesian Economics, 14(3), Spring, pp. 297-310.

\footnotetext{
${ }^{1}$ The traditional Keynesian presentation of the LT refers to a situation where the demand for money becomes infinite at a (low) positive long-term nominal interest rate owing to the behavior of speculators in
} 
the bond market (see Kregel, 2004). By contrast, Krugman (1998) refers to the LT as an episode in which the output-gap is negative despite the short-term nominal interest rate becoming zero.

${ }^{2}$ Expositions of the NC can be found in Clarida et al. (1999) and Meyer (2001) and a recent critical review is in Arestis and Sawyer (2008).

${ }^{3}$ Woodford (2003, p. 244) notes that 'it is a long-term real rate of interest rather than a short rate, that determines aggregate demand in this model' and he refers to agents' expectations about future short-term real interest rates as key determinants of aggregate demand.

${ }^{4}$ For this example, we assume "constant relative risk aversion" preferences of the representative household and that the utility of each future generation is weighted equally irrespective of size.

${ }^{5}$ The introduction of endogenous capital accumulation in the "basic" model (see Woodfrod, 2003, ch. 5) does not affect this story. In practice, investment is introduced in terms of the expansion of the capital stock that is required to underpin a predetermined potential output path so it does not play an "independent" role.

${ }^{6}$ A deflationary spiral may not necessarily set off when the economy exhibits a LT. For instance, the recent Japanese experience shows that, despite the presence of a large negative output-gap for most of the period 1991-2002, inflation turned negative in the second half of the 1990s but, after 1998, core inflation remained stable at moderately negative levels reaching its trough at -0.79 percent in 2002.

${ }^{7}$ Indeed, the high volatility of the "neutral" interest rate explains, at least partly, the practical difficulties encountered by researchers when attempting to estimate it (see Weber et al., 2008).

${ }^{8}$ Carroll and Samwick (1998) regress household's wealth on two different measures of uncertainty and find substantial evidence that households engage in precautionary saving. In particular, they find that setting the uncertainty of every household to the smallest predicted uncertainty for every household would reduce total net worth of households under 50 by about $45 \%$; would reduce their net worth exclusive of housing and business equity by $50 \%$; and would reduce their holdings of liquid assets by $32 \%$.

${ }^{9}$ See Romer (1996, pp. 333-6) for a graphical illustration of the implications of an increase in income uncertainty when the marginal utility function is convex.

${ }^{10}$ Wicksell (1911 [1958, p. 181]) discusses the possibility of a negative "natural" rate of interest when agents expect a lower real income in the future.

${ }^{11}$ Ferderer (1993) provides supportive empirical evidence for the hypothesis that, after controlling for accelerator effects and the cost of capital, increased uncertainty induces firms to postpone irreversible investment expenditures.

${ }^{12}$ Some prominent PK contributions on this topic are the studies in Dymski (1992), Wray (1991), Lavoie (1996), Neal (1996) and Wolfson (1996).

${ }^{13}$ We view the New Keynesian literature on credit rationing stemming from the seminal work by Stiglitz and Weiss (1981) as focusing on the factors that determine which borrowers are denied credit at a given point in time as opposed to the PK literature that is mainly concerned with the change over time in the amount of credit rationing for all borrowers.

${ }^{14}$ Guttentag and Herring (1984) explain the eventual occurrence of this dissonance as the result of a psychological mechanism they call "disaster myopia" whereby there is a systematic tendency for subjective probabilities to fall below actual probabilities during periods in which no major shocks occur. According to them, this mechanism explains why capital positions tend to decline in the upswing and creditors become more vulnerable to shocks that imperil their solvency. 
${ }^{15}$ Canzoneri et al. (2008) compare a "standard" NC model with no banks and monetary aggregates with a similar "enlarged" model endowed with banks that create deposits and make loans. Along other features, the "enlarged" model brings a role for government bonds in household and bank liquidity, and provides an endogenous spread between the money market rate and the rate of return in the representative agent utility function that depends mainly upon the fiscal target for the ratio of government bonds to GDP. However, other key features of the standard NC model like perfect foresight and the absence of default risk remain.

${ }^{16}$ We may also note that a fundamental implication of the "life-cycle theory of saving" is that the saving rate depends positively on the long-term rate of income growth (Modigliani and Cao, 2004).

${ }^{17}$ By contrast, the usual neoclassical justification of a significant and positive interest-elasticity of saving is based on the existence of a "wealth" effect that operates in the same direction as the "substitution" effect and thus swamps the potential offsetting impact stemming from the "income" effect (Summers, 1981).

${ }^{18}$ Deflation gives agents an incentive to delay consumption expenditures in order to benefit from lower future prices. In addition, a negative inflation rate may affect aggregate demand adversely if lower prices increase net-debtors' real debt burden since the latter have a higher propensity to spend than net-creditors (see Palley, 2008).

${ }^{19}$ Empirical studies for the U.S. economy show that actual capacity utilization in the manufacturing sector fluctuates around 82 percent in the long run. This lends support to the notion that firms exhibit a stable "desired" rate of capacity utilization in the long run (Garner, 1994; Corrado and Mattey, 1997).

${ }^{20}$ The absence of the real interest rate as an argument in the investment function stems from the fact that empirical studies normally find that there is no significant relationship between long-term real interest rates and investment once we control for accelerator and cash-flow effects (Stiglitz, 1988, p. 310).

${ }^{21}$ Presumably, an inflation-targeting CB will tend to set the actual real interest rate below the "neutral" interest rate when current inflation is below target inflation and vice-versa.

${ }^{22}$ It must be noted that the uniqueness of the "neutral" interest rate is an implication of the existence of a unique (short-run) "inflation barrier" as enshrined in the CIER. Of course, the presence of hysteresis effects would lead to changes in the CIER over time and, hence, to changes in the "neutral" interest rate.

${ }^{23}$ According to Nakatani and Skott (2007), the low Japanese "natural" rate of growth is the result of the negative rate of growth of the labor force due to adverse demographic trends and to a low rate of growth of productivity owing to the exhaustion of the technological catch-up phase. They argue that the low "natural" growth rate generates a low profit share on capital and, hence, a low desired rate of accumulation, and refer to this situation as a "structural" LT. Likewise, low "potential" growth and a (secularly) high aggregate saving rate are, according to Krugman (1998, p. 173), crucial factors behind the recent Japanese stagnation.

${ }^{24}$ This is typically justified by the presence of "learning by doing" effects, induced technical change, changes in participation rates, and migration (see, for instance, León-Ledesma and Thirlwall, 2002). 